\title{
Key Variables Account for Greater Revenue Among Community College Foundations
}

Received (in revised form): April 8, 2004

\section{Sharon M. Carrier}

Sharon M. Carrier is assistant provost for planning and special projects at Rollins College in Winter Park, Florida. She completed her doctoral degree in higher education administration at the University of Florida in December 2002. She received the 2003 John Grenzebach Research Award for outstanding doctoral dissertation (cowinner) in philanthropy for educational advancement and Dissertation-of-the-Year Award, 2003 honorable mention, from the Council for the Study of Community Colleges. Her research interests include philanthropy, strategic planning, systems development and evaluation, and leadership.

\begin{abstract}
As public community colleges continue to face constrained budgets and restricted state support, they must maximize their pursuit of philanthropic support and the performance of the foundations established at their institutions for this purpose. In a recent study, community college resource development professionals nationwide were surveyed regarding their institutional foundations. The results showed that the foundations bringing in the most annual revenue were those associated with colleges that had the largest endowments, had foundation board members deemed to be very critical to the foundation operation, and had the largest enrollments. The findings underscore the importance of building a tradition of successful fund raising and fostering foundation board member leadership. Attention to these key
\end{abstract}

Author's Contact Address:

Sharon M. Carrier, Ph.D.

Assistant Provost for Planning and Special Projects

Rollins College

1000 Holt Ave.-2712

Winter Park, FL 32789-4499, USA

Phone: + 14076462355

Fax: + 14076462351

e-mail: scarrier@rollins.edu variables may provide for greater fundraising potential for community colleges nationwide.

Keywords:

philanthropy, fund raising, voluntary support, bigher education, community college

foundations, leadership

\section{Introduction}

The escalating costs involved in fund raising, along with the tremendous benefits that an organization can realize through fund-raising success, make it critical to discern what factors influence fund-raising results. ${ }^{1}$ College presidents, governing boards, and fund raisers want to know which organizational elements and techniques are associated with more effectiveness, yet the success of fundraising programs is not often analyzed with attention to institutional size, location, degree level, mission, and other important factors. ${ }^{2}$

Differences in institutional type have been shown to be important in identifying the characteristics of effective fund-raising operations. ${ }^{3}$ The number and wealth of alumni (capacity), the maturity of the fund-raising program (history), and 
the institutional priority-including resource commitment (effort)-have been linked to effectiveness when comparing resource development programs of various institutional types. ${ }^{4}$ The existing literature regarding philanthropy and higher education, however, mostly pertains to four-year institutions with long histories of giving and well-established offices of institutional advancement. ${ }^{5}$ While community colleges have adopted elements from the senior institution models of institutional advancement, these four-year institutions, with their fully staffed development offices, sizable endowments, and strong alumni support, are not characteristic of most community colleges. ${ }^{6}$

America's community colleges continue to provide social benefits that traditionally have not been the focus of other forms of higher education. Sixty-eight percent of the students starting college at age 30 or older begin their studies at a community college. ${ }^{7}$ Additionally, community colleges enroll almost half of the US undergraduate minority population and provide much of the nation's workforce education, training, and welfare-to-work programs. ${ }^{8}$ By offering local accessibility, low tuition costs, open admissions, and remedial opportunities, community colleges have served the educational needs of students regardless of their economic status, educational background, and skills. ${ }^{9}$

The percentage of all state appropriations to higher education in the early 1990s ranged from 12 to 15 percent but by mid-decade fell to about 8 to 11 percent. Increased spending for medical services, corrections, K-12 education, welfare, and various other public agencies, as well as the recession of the early 1990s and a near moratorium on raising taxes, compressed the funds available for higher education. ${ }^{10}$
In response to unsteady tax-dollar support and cuts in state appropriations, public colleges and universities increasingly have sought and relied upon support from the private sector. ${ }^{11}$ Foundations, most often associated with institutions created under state statute, have allowed such institutions a vehicle for fund raising, provided flexibility in administrative and investment decisions, and encouraged volunteer involvement and leadership. ${ }^{12}$ The statutory restrictions that apply to college staff and governing boards do not apply to foundations, which have organizational and legal independence from the colleges they serve to enhance. ${ }^{13}$ As separately incorporated entities with 501(c)(3) approval from the Internal Revenue Service, foundations have encouraged tax-deductible contributions; developed portfolios; held, managed, and leased property; and established and secured income from various college auxiliaries. ${ }^{14}$ These foundations have forged productive partnerships, provided discretionary funds, and served as safety nets and as catalysts for change. ${ }^{15}$

Community colleges were the last segment of higher education to engage in fund raising. ${ }^{16}$ Passage of the 1965 Higher Education Act, tax-exemption rulings by the Internal Revenue Service, and the decline in public funds positively influenced the establishment of community college foundations, rare before the 1970s, but commonplace by $1980 .{ }^{17}$ This growth paralleled that of community colleges, which, in 1960 , served 11 percent of the total enrollment in higher education, compared with 35 percent of the total by $1979 .{ }^{18}$

A lack of comprehensive data on community college foundation performance has precluded accurate analysis of the value added by these 
foundations. ${ }^{19}$ The only consistent national data for resource development activity in higher education are gained through the Voluntary Support of Education annual survey. ${ }^{20}$ While the Council for Aid to Education has conducted the annual Voluntary Support of Education (VSE) survey since 1954-5, participation has never been more than half of all higher education institutions and has varied greatly by institutional type. ${ }^{21}$ In 1998 and 1999, only 75 public community colleges participated in the VSE survey, and in 2000, only 73 reported. ${ }^{22}$ Compounding the problem of a lack of data about the performance of community college foundations is that the majority of the literature regarding community colleges does not account for the diversity in institutional size, geographic location, and governance among these colleges. ${ }^{23}$

\section{Overview of the Study}

In a recent study of public community colleges nationwide, it was shown that certain institutional variables accounted for greater foundation revenue. ${ }^{24}$ The study examined the annual revenue of United States public community college foundations in relation to selected variables associated in the literature with successful foundation performance to determine whether greater levels and integration of key variables could be associated with increased foundation revenue. This national study, its findings, and implications are described in this paper.

\section{Statement of Variables, Delimitations, and Limitations}

The measure of successful foundation performance for the study was total annual dollars raised. The outcome variable measuring foundation performance was the amount of foundation revenue gained in 1998-9 from individuals, community organizations, corporations, external foundations, state matching programs, and endowment interest and investments. The study examined the resource development function connected only with funds gained in connection with private giving and foundation operations, not grant development, contract operations, property holdings, or auxiliary functions. Socioeconomic conditions, tax laws, and the fluctuation of public support possibly affecting philanthropic giving were factors beyond the scope of the study.

The selected explanatory variables for the study consisted of the foundation operating budget (including salaries and benefits); the degree to which the president, chief resource development officer, and foundation board member individually were rated as playing a critical role in the foundation operation; the degree to which meeting institutional strategic goals was rated as an important factor in evaluating the foundation operation; the college geographic location (rural/suburban/urban); the college size or credit enrollment in nonduplicated student headcount; and the college endowment.

Data regarding community college foundation operations were based on 1998-9 fiscal records and/or estimates as well as the knowledge and perceptions reported by individual resource development professionals who responded to the survey. In cases where respondents did not provide fall 1998 enrollment information, data were obtained through the Integrated Postsecondary Education Data System (IPEDS). ${ }^{25}$ 


\section{Instrumentation}

The survey's purpose was to provide baseline data for an analysis of community college resource development functions, characteristics, and performance in both grants and foundation operations. The survey was developed in response to interest from the Council for Resource Development (CRD), an affiliate of the American Association of Community Colleges (AACC). A University of Florida research team, including the author, developed the survey questionnaire, which was validated by two review panels primarily comprising members of the CRD Executive Board and CRD Board of Directors. In addition to CRD's support, the survey received financial support from the Clements Group, an institutional advancement and resource development consulting firm, and was endorsed by the Association of Community College Trustees (ACCT).

\section{Research Population}

In July of 2000, CRD mailed the final survey questionnaire to the membership of the AACC and CRD combined. The membership lists provided a research population of approximately 1,100 community colleges. A second mailing of the survey was sent in January 2001 to those who had not responded. Collection of survey results continued through February of 2001.

For the author's study, the population was limited to the two-year United States public community colleges that held membership in CRD for one or more years between 1998 and $2001 .^{26}$ It was determined that between 1998 and 2001 the annual average number of two-year United States public community colleges belonging to CRD was 650 . Of the 380 total surveys returned, 362 (56\%) were from this target population of 650 public community colleges.

\section{Descriptive Profiles}

Tables 1 and 2 provide sample profiles by college structure and geographic location. Nearly 90 percent of the sample indicated being from a single community college campus or a multicampus district. Almost 57 percent designated either urban or suburban for the geographic location of the institution; rural was the geographic location for just over 43 percent of the sample.

Of the 350 sample respondents who reported on the year the college was established, $118(34 \%)$ were founded between 1852 and 1959, and 232 (66\%) were founded between 1960 and 1999. Of the sample, $342(94.5 \%)$ indicated that a foundation or private gift development office existed at their institutions, 17 (4.7\%) answered that there was not such an office, and three $(0.8 \%)$ did not respond. The date of establishment for

Table 1: Profile of sample by college structure

\begin{tabular}{lrc}
\hline College structure & $\boldsymbol{n}$ & Percent \\
\hline Multicollege district & 36 & 9.9 \\
Multicampus district & 146 & 40.3 \\
Single community college campus & 177 & 48.9 \\
Other & 3 & 0.8 \\
\hline
\end{tabular}

$n=362$

Table 2: Profile of sample by geographic location

\begin{tabular}{lll}
\hline Geographic location & $\boldsymbol{n}$ & Percent \\
\hline Rural & 156 & 43.1 \\
Urban & 105 & 29.0 \\
Suburban & 101 & 27.9 \\
\hline
\end{tabular}

$n=362$ 
foundation offices ranged from 1944 to 2000. The highest number of foundation offices established (122 or 33.7\%) occurred during the 1980s.

Regarding the responsibility for the resource development function, 285 $(78.7 \%)$ of the sample answered "yes" to having a chief resource development officer or person with similar responsibilities at their institution; 74 $(20.4 \%)$ answered "no," and three $(0.8 \%)$ did not respond. A total of 291 (80.4\%) indicated the reporting line for the chief resource development officer or person with similar responsibilities: 13 (3.6\%) reported to the chancellor, $58(16 \%)$ to the district president, $141(39 \%)$ to the campus president, $46(12.7 \%)$ to a vicepresident, and 33 (9.1\%) to "other."

\section{Descriptive Results}

The descriptive statistics of the measures included in the analysis for the overall sample are shown in Table 3. The average response reported indicates the total score divided by the number of items of the scale. For example, since the responses regarding the roles of the college president, chief development officer, and foundation board member are on a fourpoint Likert scale, an average response of 3.708 for President suggests that, on average, the responses were between the two categories, "4-very critical" and "3critical." Likewise, an average response of 3.556 for Chief development officer and 3.684 for Foundation board member suggests that, on average, the responses were between the two categories " 4 -very critical" and "3-critical." For Institutional strategic goals, the average response of 3.330 shown in Table 3 suggests that, on average, the responses were between the two categories, "4-very important" and "3-important." For each of these variables-President, Chief development officer, Foundation board member, and Institutional strategic goalsthere was general concurrence on the critical nature or importance of each to the foundation operation as indicated by the high mean scores. The average foundation revenue was $\$ 1,010,694.1$. The average foundation operating budget was $\$ 232,479.08$. College endowments averaged $\$ 2,220,436.6$, and the average college size was $9,251.075$ students.

\section{Multiple Regression Results}

A simultaneous multiple regression test was performed to determine the extent to which the proposed regression model described the sampling data and to examine the degree of association between the outcome variable and the explanatory variables. The significance level for all

Table 3: Descriptive statistics of outcome and explanatory variables

\begin{tabular}{llll}
\hline Variables & $\boldsymbol{n}$ & $\boldsymbol{M}$ & $\boldsymbol{S D}$ \\
\hline Foundation revenue & 318 & $\$ 1,010,694.1$ & $1,894,879.981$ \\
Foundation operating budget & 300 & $\$ 232,479.08$ & $463,595.589$ \\
President & 343 & 3.708 & 0.669 \\
Chief development officer & 340 & 3.556 & 0.925 \\
Foundation board member & 342 & 3.684 & 0.672 \\
Institutional strategic goals & 342 & 3.330 & 0.889 \\
Size & 362 & $9,251.075$ & $11,049.240$ \\
Endowment & 310 & $\$ 2,220,436.6$ & $3,669,468.619$ \\
\hline$n=362$ & & &
\end{tabular}


statistical tests was fixed at a $=0.05$. The "missing listwise" option was selected for treating records with missing data.

The $R^{2}$ of 0.514 for the model was statistically significant, $F(9,274)=32.260$, $p<0.001$, suggesting that the explanatory variables were jointly associated with 51.4 percent of the foundation revenue variance. The adjusted $R^{2}$ was .499 . The high magnitude of the $R^{2}$ indicated a strong joint association that holds for the population. The regression equation for the model was as follows: foundation revenue $=-2,748,994+0.0818$ (foundation operating budget) $+263,786.41$ (critical role of college president) $+-178,650.7$ (critical role of chief development officer) $+471,995.79$ (critical role of foundation board member) + 172,199.36 (importance of meeting institutional strategic goals) + 29,818.832 (college geographic location: $\mathrm{X}_{1}=$ rural $)+190,597.98$ (college geographic location: $\mathrm{X}_{2}=$ urban $)+16.696$ (college size) +0.357 (college endowment).

Table 4 reports the unstandardized regression coefficients $(b)$, standardized regression coefficients $(b)$, observed tvalues, and squared semipartial correlations $\left(r^{2}\right)$. The explanatory variable for geographic location was categorical and, therefore, dummy-coded, resulting in two dummy-coded variables, $\mathrm{X}_{1}$ where rural was coded 1 and $X_{2}$ where urban was coded 1. Suburban served as the reference category. Three of the explanatory variables were statistically significant: Foundation board member $(b=$ $471,995.79, t(274)=2.360, p=0.019)$; Size $(b=16.696, t(274)=2.054, p=0.041$; and Endowment $(b=0.357, t(274)=14.211$, $p=0.000)$.

The regression coefficient indicates the expected unit change in the outcome variable for each unit change in any one explanatory variable, while holding the other ones constant. As reported in Table 4, the regression coefficient of 16.696 for Size suggests that for each additional credit student enrolled, there is an average increase of $\$ 16.70$ in foundation revenue. Likewise, the regression coefficient of 0.357 for Endowment suggests that each dollar increase in endowment funds leads to an average 0.36-cent increase in foundation revenue. Finally, the regression coefficient of 471,995.79 for Foundation board member suggests that for each unit increase (from "not applicable," to "not critical," to "critical," to "very critical") in

Table 4: Unstandardized regression coefficients, standardized regression coefficients, t-test statistics, and semipartial r-squares

\begin{tabular}{llllrlr}
\hline Variables & $\boldsymbol{b}$ & Std Error & $\beta$ & $\boldsymbol{t}$ & $\boldsymbol{p}$ & $\boldsymbol{r}^{\mathbf{2}}$ \\
\hline Intercept & $-2,748,994.00$ & $926,553.53$ & & -2.967 & 0.003 & \\
F. oper. budget & 0.0818 & 0.222 & 0.017 & 0.368 & 0.713 & 0.00 \\
President & $263,786.41$ & $213,864.91$ & 0.059 & 1.233 & 0.218 & 0.01 \\
Chief dev. off. & $-178,650.7$ & $107,932.48$ & -0.074 & -1.655 & 0.099 & 0.01 \\
F. board mmbr. & $471,995.79$ & $200,015.03$ & 0.110 & 2.360 & $0.019^{*}$ & 0.02 \\
Inst. str. goals & $172,199.36$ & $118,003.64$ & 0.064 & 1.459 & 0.146 & 0.01 \\
GEO-Rural & $29,818.832$ & $229,578.74$ & 0.007 & 0.130 & 0.897 & 0.00 \\
GEO-Urban & $190,597.98$ & $209,741.81$ & 0.048 & 0.909 & 0.364 & 0.00 \\
Size & 16.696 & 8.127 & 0.099 & 2.054 & $0.041^{*}$ & 0.02 \\
Endowment0 & 0.357 & 0.025 & 0.679 & 14.211 & $0.000^{*}$ & 0.42 \\
\hline
\end{tabular}

$* p<0.05$. 
the resource development professional's perception of the foundation board member's role, there is an average increase of $\$ 471,996$ in foundation revenue.

Obviously, such perceptions are subjective and would not, in themselves, create a difference in foundation revenue except as indicators of greater board commitment, activity, and support.

To determine the relative contribution of each explanatory variable, the squared semipartial correlation was calculated for each. The squared semipartial correlation $\left(r^{2}\right)$ represents the proportion of total variance (i.e., of the outcome variance) that is associated with any one explanatory variable over and above that of the others. The magnitude of $r^{2}$ can be examined in terms of effect size where $r^{2}$ $=0.26$ is considered to be large, $r^{2}=0.13$ is considered to be medium, and $r^{2}=$ 0.0196 is considered to be small. ${ }^{27}$ According to these criteria, for the three statistically significant variables, the effect size of Endowment $\left(r^{2}=0.42\right)$ was large, and the effect sizes of Foundation board member $\left(r^{2}=0.02\right)$ and Size $\left(r^{2}=0.02\right)$ were small, as shown in Table 4.

\section{Implications for Research and Practice}

\section{College endowment}

Of greatest influence in the model was the college endowment. That there was a significant and positive relationship between endowment size and foundation revenue reinforced existing research of postsecondary institutions. ${ }^{28}$ This finding also supported conclusions from two national studies of community colleges. ${ }^{29}$ The healthy economic environment and the 18 and 11 percent average stock market investment returns for higher education endowments in 1998 and 1999, respectively, could also help to account for the significant and positive relationship between foundation revenue and endowment in this study. ${ }^{30}$ Since endowment interest and investments were part of the foundation revenue comprising the outcome variable, institutions with larger endowments were more likely to experience larger interest and investment gains during the 1998-9 fiscal reporting period for the survey.

Originally, community college foundations collected and dispersed funds annually, without developing endowments. ${ }^{31}$ In a national survey conducted in 1987, community college presidents cited the creation of a college foundation as the entrepreneurial concept most used, second only to contract training programs in terms of having a very successful impact on the institution. ${ }^{32}$ In 1986, an endowment size of $\$ 50,000$ was considered substantial; however, in 1993, foundation endowments for 165 community colleges exceeded $\$ 1$ million. ${ }^{33}$ The 1998-9 endowments for the community colleges in this sample averaged over $\$ 2.2$ million.

The positive and significant relationship between college endowment and foundation revenue indicates that endowments have added resource development potential for community colleges that have made them a priority and underscores the importance of building a tradition of successful fundraising practices and sound resource management policies. The more successfully endowed funds are invested and managed, the stronger the base of support for future foundation performance. Managing money wisely is a significant function of the college foundation, and community college foundation board members should consider having an endowment and asset committee to oversee this important 
service to the college. ${ }^{34}$ Whether such funds are externally or internally managed, community colleges should develop an effective investment policy to guide investment decisions and to provide optimal investment returns. ${ }^{35}$

\section{Role of the foundation board member}

Of secondary influence in the model was the role of the foundation board member, also significantly and positively related to foundation revenue. This finding concurred with the literature regarding the importance of the foundation board for successful community college foundations. ${ }^{36}$ Based on this finding, encouraging strong board leadership will be essential so that foundation board members will act in ways that will best support the college. It will be important for community college leaders not only to reconsider foundation board composition and selection, but also to examine board commitment and the barriers to increased responsibility and self-direction. Creating a more proactive foundation board may involve an overhaul of the foundation bylaws and a revamping of foundation structures for more direct oversight of vital foundation functions such as raising, investing, and disbursing foundation funds. ${ }^{37}$

\section{College size}

College size proved to be positively and significantly related to foundation revenue. This finding supported previous literature that linked greater college size to more successful community college foundations and development programs. ${ }^{38}$ While significantly and positively related to foundation revenue, college size had only a small effect and should not preclude smaller institutions from implementing a resource development program or enhancing one currently in place.

\section{Foundation operating budget}

The statistically insignificant finding for foundation operating budget ran counter to the literature supporting resource allocation as an important variable for fund-raising success. ${ }^{39}$ That no significant relationship was found between foundation operating budget and foundation revenue may have resulted from differences in how foundation operations are funded and possible misunderstanding on the part of survey respondents. Funding for foundation operations can come exclusively from the host institution, from foundationgenerated resources alone, or some combination. ${ }^{40}$ Some respondents may have excluded budgetary contributions from the host institution or included all foundation assets in response to the survey question regarding foundation operating budget. Such misinterpretation may have confounded a relationship between the foundation operating budget and foundation revenue.

\section{Role of the president}

This study also found no statistically significant relationship between the critical role of the president and foundation revenue, a result that contradicted the literature specifically regarding two-year colleges. ${ }^{41}$ The finding concurred, however, with one national study of state colleges and universities. ${ }^{42}$ Survey respondents, on average, thought the president played a "very critical" or "critical" role in the institution's foundation operation. The statistically insignificant finding may be explained, in part, by the limited range of responses at the high end $(M=3.708)$ of the fourpoint Likert scale. 
It has been suggested that fund raising has not been a high priority for community college presidents. ${ }^{43}$ Moreover, it has been said that the president's understanding, advocacy, and support of the advancement function may be more critical than his or her personal solicitation of funds. ${ }^{44}$ Additionally, it has been stated that the president's leadership capacity in the area of advancement largely will determine fund-raising success for most community colleges. ${ }^{45}$ While these issues deserve further exploration, this study's findings are inconclusive regarding the relationship between the amount of foundation revenue gained and the role of the community college president.

\section{Role of the chief development officer}

Research has shown that having a chief development officer or individual responsible for external resource development is characteristic of successful foundations. ${ }^{46}$ Having someone assigned to external resource development was characteristic of community college foundations with values of $\$ 1$ million or more according to a 1992 national survey. ${ }^{47}$ Another national survey in 1997 found that the community college development officer or foundation executive director played the most active role in soliciting funds. ${ }^{48}$ While the relationship between foundation revenue and the chief resource development officer's role was statistically insignificant in this study, the finding remains inconclusive. Survey results showed a high average response $(M=3.556)$ on the fourpoint Likert scale indicating that most survey respondents in the sample rated the role of the chief development officer as "very critical" or "critical" to the foundation operation; however, at least 20 percent of the respondents did not have a chief resource development officer (or a person with similar responsibilities) at the institution, in which case "not applicable" or " 1 " on the Likert scale would have been noted on the survey.

\section{Institutional strategic goals}

Connecting college and development planning has been cited as necessary for successful community college resource development. ${ }^{49}$ That a statistically significant relationship was not found between meeting of institutional strategic goals and foundation revenue in this study may be misleading. Asked to indicate the importance that meeting institutional strategic goals had in evaluating the foundation operation, survey respondents, understandably, may have based their answers on whether the foundation was formally or informally evaluated. While the foundation may have used institutional strategic goals for planning and guiding operational decisions, the lack of a formal or informal evaluation component may have contributed to a lower response regarding the importance of this item. Still, on average, the responses were between the categories "very important" and "important," an indication that meeting institutional strategic goals was meaningful to most foundation operations. The relationship of foundation revenue to the foundation's meeting of institutional strategic goals, however, remains inconclusive.

\section{Geographic location}

No statistically significant relationship was found between foundation revenue and an urban versus a suburban location or a rural versus a suburban location. While geographic location did not prove to be a significant variable in this study, the 
literature suggested that an urban location could enhance success in development operations. ${ }^{50}$ Fund-raising potential still may be linked to an institution's location and access to resources, yet the college's geographic location, alone, may not provide the depth of information needed to determine such access to resources. Measures of regional, social, and economic conditions would enhance the understanding of environmental factors potentially affecting foundation revenue.

\section{Conclusion}

Philanthropic giving to community colleges is a relatively recent and increasingly essential activity. ${ }^{51}$ Philanthropy, entrepreneurship, and grant procurement will be necessary for decreasing overall dependency on shrinking revenue from more traditional sources. ${ }^{52}$ To meet the challenges of long-term viability, community colleges will need leaders who can present compelling evidence of institutional and student success in the community while showing that public funds are falling short of important needs. ${ }^{53}$ These leaders must recognize the necessity andpotential of a foundation and the elements that contribute to a foundation's success.

As community colleges continue to seek additional external funding, it is incumbent upon trustees, presidents, and chief resource development officers to understand research regarding resource development and the implications of such research for their institutions. Attention to key variables for resource development in community colleges may provide for greater fund-raising potential for community colleges nationwide.

\section{References}

1. M. A. Duronio and B. A. Loessin (1993),

"Management effectiveness in fundraising," in D. R. Young, R. M. Hollister, V. A. Hodgkinson, and
Associates (Eds.), Governing, Leading, and Managing Nonprofit Organizations: New Insights from Research and Practice, Jossey-Bass, San Francisco, pp. 170-90.

2. B. E. Brittingham and T. R. Pezzullo (1990), The Campus Green: Fund Raising in Higher Education, ASHE-ERIC Higher Education Report No. 1, George Washington University, School of Education and Human Development, Washington, DC.

3. M. A. Duronio and B. A. Loessin (1991), Effective Fund Raising in Higher Education: Ten Success Stories, Jossey-Bass, San Francisco.

4. Brittingham and Pezzullo (1990), The Campus Green, op. cit.

5. K. Phillippe and I. R. Eblinger (1998), Community College Foundations: Funding the Community College Future, Research Brief 98-3, American Association of Community Colleges, Washington, DC.

6. J. C. Glass, Jr. and K. L. Jackson (1998), "Integrating resource development and instructional planning," Community College Journal of Research and Practice, 22, 8, pp.715-39; Phillippe and Eblinger (1998), Community College Foundations, op. cit.

7. A. Cohen and F. Brawer (1996), The American Community College, 3rd edn., Jossey-Bass, San Francisco.

8. K. A. Phillippe and M. Patton (2000), National Profile of Community Colleges: Trends \& Statistics, 3rd edn., American Association of Community Colleges, Community College Press, Washington, DC.

9. R. Gillett-Karam, S. Roueche, and J. Roueche (1991), Underrepresentation and the Question of Diversity: Women and Minorities in the Community College, American Association of Community and Junior Colleges, Washington, DC.

10. R. L. Alfred (1996), "Competition for limited resources: Realities, prospects, and strategies," in D. S. Honeyman, J. L. Wattenbarger, Jr., and K. C. Westbrook (Eds.), A Struggle to Survive: Funding Higher Education in the Next Century, Corwin Press, Thousand Oaks, CA, pp. 209-28; D. Leslie and E. K. Fretwell, Jr. (1996). Wise Moves in Hard Times: Creating o Managing Resilient Colleges \& Universities, Jossey-Bass, San Francisco.

11. A. H. Moore (2000), Public-Policy Influences on Public College and University Foundations, Occasional Paper No. 40, Association of Governing Boards of Universities and Colleges, Washington, DC, January.

12. R. B. Rennebohm, (1981), "Uses of the in-house foundation," in F. C. Pray (Ed.), Handbook for Educational Fund Raising: A Guide to Successful Principles and Practices for Colleges, Universities, and Schools, Jossey-Bass, San Francisco, pp. 316-21.

13. Cohen and Brawer (1996), The American Community College, op. cit.

14. K. B. Woodbury, Jr. (1989), "Foundations," in G. J. Ryan and N. J. Smith (Eds.), Marketing and Development for Community Colleges, Council for Advancement and Support of Education, Washington, DC, pp. 171-80.

15. Moore (2000), Public-Policy Influences, op. cit. 
16. J. M. Anderson and T. Snyder (1993), The Community College Foundation Manual \& Guide, ERIC Document Reproduction Service No. ED 365 369, Network of Community College Foundations, Rancho Cucamonga, CA; Brittingham and Pezzullo (1990), The Campus Green, op. cit.

17. D. Angel and D. Gares (1989), "The community college foundation today: A history, characteristics, and assets," in A. M. Cohen and F. B. Brawer (Series Eds.) and J. L. Catanzaro and A. D. Arnold (Vol. Eds.), New Directions for Community Colleges: No. 68. Alternative Funding Sources, Jossey-Bass, San Francisco, pp. 5-14.

18. D. W. Breneman and S. C. Nelson (1981), Financing Community Colleges, The Brookings Institution, Washington, DC.

19. W. M. Craft and K. E. Guy (2002), "Community college fundraising prospects for the future," Community College Journal, 72, 4, pp. 28-32.

20. Glass and Jackson (1998), "Integrating resource development and instructional planning," op. cit.

21. Council for Aid to Education (2000), Voluntary Support of Education 1999, Council for Aid to Education, New York.

22. Ibid.; Council for Aid to Education (2001 Voluntary Support of Education 2000, Council for Aid to Education, New York.

23. S. G. Katsinas (1996), "Preparing leaders for diverse institutional locations," in A. M. Cohen and F. B. Brawer (Series Eds.) and J. C. Palmer and S. G. Katsinas (Vol. Eds.), New Directions for Community Colleges: No. 95. Graduate and Continuing Education for Community College Leaders: What it Means Today, Jossey-Bass, San Francisco, pp. 15-25.

24. S. M. Carrier (2002), "The relationship of selected institutional variables to community college foundation revenue," Ph.D. dissertation, University of Florida.

25. U.S. Department of Education (1998), National Center for Education Statistics (NCES) Integrated Postsecondary Education Data System (IPEDS), "Fall enrollment 1998-99 (final release, January 2002)," <http://nces.ed.gov/Ipeds/ef9899/>.

26. Council for Resource Development (1998), 19981999 Membership Directory \& Resource Guide, Council for Resource Development, Washington, DC; Council for Resource Development (1999), 19992000 Membership Directory, Council for Resource Development, Washington, DC; Council for Resource Development (2000), 2000-2001 Membership Directory, Council for Resource Development, Washington, DC; Council for Resource Development (2001), 2001-2002 Membership Directory, Council for Resource Development, Washington, DC.

27. J. Cohen (1988), Statistical Power Analysis for the Behavioral Sciences, 2nd edn., L. Erlbaum Associates, Hillsdale, NJ.

28. Brittingham and Pezzullo (1990), The Campus Green, op. cit.; J. O. Dean, Jr. (1985), "Educational fund- raising in church-affiliated colleges: A predictive and prescriptive model," Ph.D. dissertation, The

University of Alabama; Duronio and Loessin (1993), "Management effectiveness in fundraising," op. cit.; W. L. Pickett (1977), "An assessment of the effectiveness of fund raising policies of private undergraduate colleges," Ph.D. dissertation, University of Denver.

29. B. Glandon and B. J. Keener (1994), Going Public with Private Fund Raising: Profiles, Patterns and Perceptions of Community College Foundation Performance, National Council for Resource Development, Washington, DC, December; C. B. Hunter (1987), "Fund-raising from private sources in public community colleges using not-for-profit foundation boards," Ed.D. dissertation, West Virginia University.

30. M. Van der Werf (1999), "A bull market gave colleges 18\% return on endowments in 1998," The Chronicle of Higher Education, February 19, A44; J. L. Pulley (2000), "Endowments earned 11\% in 1999, down from 18\% the prior year," The Chronicle of Higher Education, February 18, A46.

31. K. B. Woodbury, Jr. (1989), "Foundations," in G. J. Ryan and N. J. Smith (Eds.), Marketing and Development for Community Colleges, Council for Advancement and Support of Education, Washington, DC, pp. 171-80.

32. W. L. Deegan (1989), "Entrepreneurial management: A fourth concept of college management for the decade ahead," in T. O'Banion (Ed.), Innovation in the Community College, American Council on Education and Macmillan, New York, pp. 200-14.

33. K. Adams, B. Keener, and A. McGee (1994), "Going public with private fund raising: Community colleges garner fairer share of support," Community College Journal, 65, 1, pp. 39-42.

34. S. G. Katsinas, S. E. Herrmann, and H. J. Traylor (1990), "Challenges for community college foundations," AGB Reports, 32, 4, pp. 23-6.

35. E. D. Kapraun and D. A. Heard (1993), Financing Community Colleges: Threats and Opportunities, ERIC Document Reproduction Service No. ED 352 081, University of Arkansas, Fayetteville.

36. L. M. Degerstedt (1982), "The strategies and perceptions of community colleges and the foundation: A national perspective," in W. H. Sharron, Jr. (Ed.), The Community College Foundation, National Council for Resource Development, Washington, DC, pp. 49-66; C. B. Hunter (1987), "Fund-raising from private sources," op. cit.; W. H. Sharron, Jr. (1982), "The case for the community college foundation," in W. H. Sharron, Jr. (Ed.), The Community College Foundation, National Council for Resource Development, Washington, DC, pp. 299_ 321.

37. Katsinas et al., (1990), "Challenges for community college foundations," op. cit.

38. B. L. Glandon (1987), "Critical components of successful two-year college foundations," Ed.D. dissertation, Brigham Young University; C. C. 
Maples (1980), "An analysis of development programs at selected two-year institutions in the United States," Ed.D. dissertation, The University of Alabama; Phillippe and Eblinger (1998), Community College Foundations, op. cit.; G. J. Ryan (1993), "The fund raising and economic development linkage," in G. J. Ryan (Ed.), Partners in Economic Development: Community College Strategies for Collaboration, American Association of Community Colleges, Washington, DC, pp. 59-64.

39. Brittingham and Pezzullo (1990), The Campus Green, op. cit.; Duronio and Loessin (1991), Effective Fund Raising in Higher Education, op. cit.; M. Glennon (1985), "Fund raising in small colleges: Strategies for success," Ed.D. dissertation, The George Washington University; F. D. Hunter (1987), "Private fund raising by American Association of State Colleges and Universities member institutions," Ph.D. dissertation, The University of Mississippi; E. B. Ironfield (1991), "Characteristics of two-year public colleges and foundations with successful fund-raising programs," Ed.D. dissertation, University of Massachusetts; P. J. Jenner (1987), "Factors associated with success of resource development programs at California community colleges," Ed.D. dissertation, University of San Diego; J. J. Johnson (1986), “A profile of selected high- and low-performing nonprofit foundations in public community, technical, and junior colleges in the United States," Ed.D. dissertation, Virginia Polytechnic Institute and State University; J. W. Leslie (1969), Focus on Understanding and Support: A Study in College Management, American College Public Relations Association, Washington, DC; W. C. Levis (1991), "Investing more money in fund raising-wisely," in D. F. Burlingame and L. J. Hulse (Eds.), Taking Fund Raising Seriously, Jossey-Bass, San Francisco, pp. 25771; M. F. Luck (1974), "The characteristics of foundations and fund-raising in public comprehensive two-year colleges," Ph.D. dissertation, Southern Illinois University at Carbondale; M. F. Luck and D. J. Tolle (1978), Community College Development: Alternative Fund-raising Strategies, $\mathrm{R} \& \mathrm{R}$ Newkirk, Indianapolis; C. C. Maples (1980), "An analysis of development programs," op. cit.; S. D. Miller (1991), "The relationship of selected factors with success in private sector resource acquisition at Appalachian higher education institutions," Ph.D. dissertation, The Union Institute; W. L. Pickett (1977), "An assessment of the effectiveness of fund raising policies," op. cit.

40. R. C. Hedgepeth (1999), "Creating a successful affiliated foundation," Foundation Relations. Board Basics, ERIC Document Reproduction Service No. ED 428 598, Association of Governing Boards of Universities and Colleges, Washington, DC; C. R. Simic (1998), "The role of the foundation board," Foundation Relations. Board Basics, ERIC Document Reproduction Service No. ED 428 596, Association of Governing Boards of Universities and Colleges, Washington, DC.

41. D. E. Bock and W. R. Sullins (1987), "The search for alternative sources of funding: Community colleges and private fund-raising," Community College
Review, 15, 3, pp. 13-20; E. F. Duffy (1979), "Evaluative criteria for community college foundations," Ph.D. dissertation, University of Florida; Glandon and Keener (1994), Going Public with Private Fund Raising, op. cit.; J. C. Glass, Jr. and K. L. Jackson (1998), "A new role for community college presidents: Private fund raiser and development team leader," Community College Journal of Research and Practice, 22, 6, pp. 575-90; Glennon (1985), "Fund raising in small colleges," op. cit.; Ironfield (1991), "Characteristics of two-year public colleges and foundations," op. cit.; K. L. Jackson and C. J. Glass, Jr. (2000), "Emerging trends and critical issues affecting private fund-raising among community colleges," Community College Journal of Research and Practice, 24, 9, pp. 729-44; B. J. Keener (1982), "The foundation's role in resource development," in W. H. Sharron, Jr. (Ed.), The Community College Foundation, National Council for Resource Development, Washington, DC, pp. 3-17, B. J. Keener, G. J. Ryan, and N. J. Smith (1991), "Paying attention pays off: How to market resource development," Community, Technical, and Junior College Journal, 62, 1, pp. 34-7; R. Mosier (1980), The Role of the College President in Resource Development, Resource Paper No. 24, National Council for Resource Development, Washington, DC, June; D. G. Robinson (1989), "The president and institutional advancement," in G. J. Ryan and N. J. Smith (Eds.), Marketing and Development for Community Colleges, Council for Advancement and Support of Education, Washington, DC, pp. 15-20; G. J. Ryan, (1988), "Excellence in educational fundraising at America's community colleges," Community/Junior College Quarterly of Research and Practice, 12, pp. 311-27; G. J. Ryan (1989), "Reasons for success," in J. L. Catanzaro and A. D. Arnold (Series Eds.) and A. M. Cohen and F. B. Brawer (Vol. Eds.), New Directions for Community Colleges: No. 68. Alternative Funding Sources, Jossey-Bass, San Francisco, pp. 15-20.

42. F. D. Hunter (1987), "Private fund raising," op. cit.

43. Ryan (1993), "The fund raising and economic development linkage," op. cit.

44. G. J. Ryan (1994), "The president's role in fund raising," in R. J. Pappas (Ed.), Strategic Marketing for Presidents, American Association of Community Colleges, Washington, DC, pp. 81-7.

45. Glass and Jackson, 1998, "A new role for community college presidents," op. cit.

46. Glandon and Keener (1994), Going Public with Private Fund Raising, op. cit.; C. B. Hunter (1987), "Fund-raising from private sources," op. cit.

47. Glandon and Keener (1994), Going Public with Private Fund Raising, op. cit.

48. Phillippe and Eblinger (1998), Community College Foundations, op. cit.

49. J. Blong and B. Bennett (1991), "Empty wells: Resource development in tough times," Community, Technical, and Junior College Journal, 62, 1, pp.30-3; D. E. Daniel (1985), Future Trends in Resource Development, Resource Paper No. 34, National 
Council for Resource Development, Washington, DC, November; Glandon and Keener (1994), Going Public with Private Fund Raising, op. cit.; W. Hooks and S. Kelley (1990), The Effective Linkage of Planning and Resource Development: A Process that Works, Resource Paper No. 43, National Council for Resource Development, Washington, DC, May; Keener (1982), "The foundation's role in resource development," op. cit.; S. Robison (1982), "The development of the two-year college foundation and techniques of success," in W. H. Sharron, Jr. (Ed.), The Community College Foundation, National Council for Resource Development, Washington, DC, pp. 31-48; Ryan (1994), "The president's role in fund raising," op. cit.; J. L. Wattenbarger (1982), "The case for the community college foundation," in W. H. Sharron, Jr. (Ed.), The Community College Foundation, National Council for Resource Development, Washington, DC, pp. 19-28.

50. Brittingham and Pezzullo (1990), The Campus Green, op. cit.; M. Bulpitt (1982), "The multi-unit urban district and the foundation," in W. H. Sharron, Jr. (Ed.), The Community College Foundation, National Council for Resource Development, Washington, DC, pp. 193-210; A. C. Gatewood (1994), “A comparative analysis and evaluation of community college nonprofit foundations in North Carolina," Ed.D. dissertation, North Carolina State University; C. B. Hunter (1987), "Fund-raising from private sources," op. cit.; F. D. Hunter (1987), "Private fund raising," op. cit.; Ironfield (1991), "Characteristics of two-year public colleges and foundations," op. cit.; Ryan (1993), "The fund raising and economic development linkage," op. cit.

51. Brittingham and Pezzullo (1990), The Campus Green, op. cit.

52. A. L. Lorenzo and N. A. LeCroy (1994), “A framework for fundamental change in the community college," Community College Journal," 64, 4, pp.14-19.

53. J. A. Johnson (1986), "Advancement strategies for two-year colleges," in A. W. Rowland (Ed.), Handbook of Institutional Advancement: A Modern Guide to Executive Management, Institutional Relations, Fund-Raising, Alumni Administration, Government Relations, Publications, Periodicals, and Enrollment Management, 2nd edn., Jossey-Bass, San Francisco, pp. $706-21$.

\section{Practitioner's Perspective}

Over the last four decades, community colleges have experienced phenomenal growth as they have offered accessible, affordable education for underprivileged, nontraditional, and minority populations in the United States. However, as lowered state funding has created fiscal challenges, more community colleges are joining fouryear institutions in creating comprehensive foundations. Noting that existing research about philanthropy and higher education focuses primarily on four-year institutions, Sharon Carrier of Rollins College begins a needed dialogue about foundation revenue pertaining to community colleges.

Carrier examines the relationship of key institutional variables to greater foundation revenue. Basing survey data on 1998-9 fiscal records of 362 community college foundations, Carrier concludes that an important variable related to foundation success is the college endowment: the stronger and more well-managed the current college endowment, the stronger will be future foundation performance.

Similarly, the role of the foundation board member is correlated to strong foundation revenue. College size is another significant variable: the greater the college size, the more likelihood of foundation success. While cautioning that various factors may have interfered, Carrier finds no statistically significant correlations between the foundation's revenue and its operating budget, the degree to which the president and chief resource development officer are considered by the institution to play a critical role in foundation efforts, the degree to which meeting strategic goals is rated as an important factor, and the geographic location of the college.

Implications of Carrier's research reinforce the need for endowment offerings to become standard procedure for community college foundations. Historically, foundations have overlooked endowments for good reason: their institutions needed 
immediate building and scholarship funds for fast-growing campus enrollments. However, over the last two decades planned giving has become a priority, coinciding with anticipation of the greatest transfer of wealth in history. Along with strong endowment programs, Carrier's research also demonstrates the importance of leadership by foundation board members who lend advice to their foundations, help identify opportunities, accompany foundation staff on visits and solicitations, and help recognize donors.

It is essential that further research explore the variables about which Carrier's research shows no statistical significance. The role of the president and chief resource development officer in fund raising needs particular examination, as the lack of statistical significance is counterintuitive to the fact that successful community colleges have presidents who are immersed in fund raising even while representing the academic concerns of the college. With many presidents retiring, community colleges must determine priorities for their replacements. The president's ability to attract financial support is likely to become an even stronger priority than in the past.

Carrier's research also indicates a need for more inquiry into the variables of the foundation's operating budget and strategic goals. Experience suggests that successful fund-raising efforts have operating budgets that support a comprehensive fund-raising effort, with clear strategic goals. Consistent communication to the community about the college's unique mission is key, as is educating the public that community colleges are state-assisted, not state-supported. Foundation and communications staff, often appropriately linked in the same department for seamless communication to the public, must articulate the gaps in funding and remind the community of the college's mission of accessibility and open doors.

Community colleges make it possible for many to accomplish educational dreamspeople who in times past would not have continued their education beyond high school. Stories of these accomplishments are the very strength that community colleges bring to fund raising. Carrier's research helps establish a dialogue for inquiry that is important to all foundation practitioners and, more importantly, to future community college students. 